\title{
The Impact of Buying Direct of Educational, Health and economic Sectors toward Human Development Index
}

\author{
Abd. Rahman Rahim ,Basri Rizak \\ University of Muhammadiyah, Makassar - Indonesia
}

\begin{abstract}
This study aimed to find out the impact of direct buying in the budget revenue and expenditure on educational, health and economics sectors, either simultaneously or partially on the Human Development Index (HDI). Moreover, it can reveal the dominant variable effects on HDI. Model analysis used was multiple regression by using time series from 2004 to 2010 or 7 years as secondary data. The results of this study indicate that the variable X1 (Education) has a coefficient value of $=0.0007^{\wedge}$ (t.hit: 0.71), X2 (Health) has a coefficient of $=0.0015$ ( t thit : 2.238) and X3 (Economics) has a coefficient of $=0.0021$ (t.calculate: 4.546$)$ and the constant $=65.20$. The results of $T$ test (partial) with the significant confidence level 0.95 and 0.05 , and $t$ table $=0.3182$ against the variable, only variable X3 (the economic) that have a significant effect toward variable Y (HDI of South Sulawesi Province). The result of F test (simultaneously) with t.calc. $=72.25$ is greater than t.tabel $=9.28$ which means that the third independent variable $(X)$ have simultaneously siqnificant toward the variable Y (HDI of South Sulawesi). In addition, magnitude R $2=94.607$ shows the high influence of the independent variable (X) toward the variable Y (HDI South Sulawesi).
\end{abstract}

Keywords: Human Development Index, South Sulawesi

\section{Introduction}

The development paradigm has shifted from development of oriented production \{production centered development) in the decade of the 60's to a development paradigm that places more emphasis on the distribution of development outcomes (distribution growth development) during the decade of the 70s. Later in the decade of the 80s, emerged oriented development paradigm fulfillment of basic needs (basic need development), and finally into the development paradigm centered on human beings (human centered development) that emerged in the $1990 \mathrm{~s}$.

One way to measure the success or performance of a country or region in the field of human development to use the Human Development Index (HDI) or the Human Development Index (HDI). HDI is a composite index that includes three areas of human development that are considered fundamental that age life (longetivity), knowledge (knowledge), and a decent standard of living (decent living).

If the status of human development remains low on the criteria, this means the area of human development performance still require special attention to catch up. Similarly, if the status of human development remains high on the criteria, this means that human development still needs to be improved.

In this regard, the regional budget allocation strategy plays an important role to improve the Human Development Index. In an effort to increase the contribution to the increase HDI budget, direct allocations should be increased. Direct spending by the government can diarakan for education, health and other sectors of the economy, so the quality can be better human development.

This requires the assessment of the budget that has been realized by the South Sulawesi Provincial Government through the budget, especially the sectors related to the constituent components of the HDI. The budget allocation to primary kompenen allocation HDI is the education sector, the health sector and the economic sector.

\section{Research methods}

The research was done in the area of South Sulawesi Province from October to December 2011. The scope of research focuses on the realization of direct expenditure in Regional Budget of South Sulawesi Province and its influence on the Human Development Index. The realization of direct expenditure observed is expense in sectors of education, health and economic. The budget realization of these three sectors then analyzed their influence toward the Human Development Index.

The data used in this research is secondary data in the form of "time series" quantitatively, namely the data in the form of numbers. The sources of data obtained from the Central Statistics Agency (BPS) of South Sulawesi, Bappeda and the Finance Division of Regional Secretariat of South Sulawesi Province. The data were obtained then processed by using SPSS 17.A

Model of analysis used in analyzing the data is the econometric model. Meanwhile, the analysis technique used is the least squares models (Ordinary Least Square / OLS). The analysis of descriptive statistical 
was done in order to know the budget ratio of education, health and the economy, as well as total of direct expenditure and regional budget expenditure.

Meanwhile, inferential statistical analysis method to be used is the method of Multiple Linear Regression Analysis (Multiple Linear Regression). In general, the function of multiple linear regression equation to be used in quantitative analysis for the implementation of this study, it can be formulated as follows: $\mathrm{Y}=\mathrm{b} 0+\mathrm{b} 1 \mathrm{X} 1+\mathrm{b} 2 \mathrm{X} 2+\mathrm{b3} \mathrm{X3}+\mathrm{Ei}$

Where:

$\mathrm{Y}=$ Human Development Index

$\mathrm{X} 1=$ Direct expenditure Education Sector

$\mathrm{X} 2=$ Direct Health Expenditure X3 $=$ Shopping Direct Economic Sector b0 = Constant

bi $=$ Coefficient influence variable $\mathrm{X} \mathrm{Ei}=$ Coefficient error

Testing the level of influence significance from variable independent toward the dependent variable was done by using Fisher test (F-test) at a rate of $95 \%$, while the analysis of influence of each independent variable will be performed by t test (t-test) at a rate $95 \%$.

There are some terms used in the implementation of this study can be formulated as follows:

- The Human Development Index

- Direct Expenditure

- Direct expenditure of education sector

- Direct expenditure of health sector $\bullet \quad$ Direct expenditure of economic sector

- Budget Regional of South Sulawesi Provincve.

\section{Results And Discussion}

To prove the hypothesis proposed in this study, then in testing conducted OLS (ordinary least square). OLS is a quantitative analysis method to calculate the regression coefficients of the close relationship between the independent variables with the dependent variable either partially or simultaneously. The variables used in the calculations consists of Jump Shopping Education Sector, Health Sector Direct Shopping and Shopping Direct Economic Sector as an independent variable and the Human Development Index of South Sulawesi as the dependent variable. All data is a time series that began in 2004-2010.

To perform tests performed using linear regression equation model with the following formula:

$\mathrm{Y}=\mathrm{BO} \mathrm{XI}+\mathrm{bl}+\mathrm{b} 2 \mathrm{X} 2+\mathrm{b} 3 \mathrm{X} 3+\mathrm{Ei}(1)$ Where:

$\mathrm{Y}=$ Human Development Index of South Sulawesi Shopping Direct XI = X2 = Education

Sector Healthcare Sector Shopping Direct Shopping Direct X3 = Bo = constant Economic Sector bi = coefficient of influence of variable $\mathrm{X} \mathrm{Ei}=$ coefficient of error In the $\mathrm{t}$ test was performed to see the conclusions significance value of t-statistic values are shown. If the significance value of a variable higher than $a=5 \%(0.05)$, it can be concluded that the independent variable on the dependent variable is significant or have any effect on the dependent variable. Conversely, if the value of a variable of significance is lower than the a $=5 \%(0.05)$, it can be concluded that the independent variables are not significant to the dependent variable.

\section{Variable XI: Buying Direct of Educational Sector have significant effect on thHeDI South Sulawesi}

The results of statistical calculations for variable Shopping Direct Education Sector (XI), obtained $t$ value $t 0.71$ with a significance of 0.95 . At the $95 \%$ confidence level $(\mathrm{a}=0.05)$ with df $3 \mathrm{t}$ table values obtained for the t count $3.182(0.071)<t$ table (3.182) or sig (0.95)> a (0.05). Based on these data indicate that the direct effect of the Education Sector Expenditures (XI) to HDI (Y) is not significant. Thus Ha Ho accepted and rejected.

\section{Variable X2: Shopping Direct HealthcaSrector Index significantly influence Human Development}

The results of statistical calculations for variable Shopping Direct Health Sector (X2), obtained t value t 2.238 with a significance of 0.11 . At the $95 \%$ confidence level $(a=0.05)$ with of 3 obtained $t$ value table is 3.182, then $t$ count $(2.238)<t$ table (3.182) or sig (0.11) $>$ a (0.05). Based on these data indicate that the effect of Lansgung Sector Health Expenditure (X2) to HDI

(Y) is not significant. Thus Ha Ho accepted and rejected.

Variable X3: Shopping Direct Economic Sectors significant effect on the HDI South Sulawesi

The results of statistical calculations for variable Shopping Direct Economic Sector (X3), obtained $t$ value $t$ 4.546 with a significance of 0.02 . At the $95 \%$ confidence level $(\mathrm{a}=0.05)$ with df 3 obtained $\mathrm{t}$ value table is 
3.182, then $\mathrm{t}$ count $(4.546)>\mathrm{t}$ table $(3.182)$ or $\operatorname{sig}(0.02)<\mathrm{a}(0.05)$. Based on these data indicate that the influence of Shopping Direct Economic Sector (X3) to HDI (Y) is significant. Thus, Ho is rejected and Ha accepted.

\section{F Test}

F test or Anova test were used to determine whether simultaneously or jointly affect the significance of independent variables or the dependent variebel Based on calculations derived values SPSS version 17.0 F count $=72.25$ with a significance of 0.003. Using the 0.05 level of significance table value obtained $\mathrm{F}$ table is 9.28. Then F count (72.25)> F table (9.28), or the significance of F of 0.04 indicates less than 0.05 . Thus Ha and Ho ditotolak accepted, so the hypothesis that there Simultaneous Shopping Direct Effect In the Education Sector, Health Sector and Economic Sector Against Human Development Index of South Sulawesi.

\section{Determination Coefficient Tes(tR2)}

The coefficient of determination is used to test the goodness of-fit of the regression model that can be seen from the value of R Square. To determine the level of development of HDI in South Sulawesi, which caused a few to several factors Shopping Direct Education Sector (XI), Shop Direct Health Sector (X2) and Shop Direct Economic Sector (X3) can be seen through the coefficient of determination. From the calculation of Adjusted R Square is 0.946069 . This shows the strong influence of the relationship between the variables $\mathrm{Y}$ (HDI) with independent variables XI (education), X2 and X3 Health (Economics). Thus the Human Development Index of South Sulawesi can be explained by the four independent variables above, while the remaining 5.4 percent are influenced by other variables.

The development of South Sulawesi based on current prices PDRB at current prices is one of the indicators of economic development that describes how the role of each sector in the economic development of the area. In the past few years, namely between the years 2006-2010 and based on indicators of economic development, it appears South Sulawesi's economy has undergone a pretty good improvement, as seen in the increase in the value of PDRB in 2006 which only reached Rp. 60.9 trillion more, but with the implementation of various government policies at the central and local governments, the indicator of economic development has been able to reach Rp. 117.8 trillion more in 2010.

\section{South Sulawesi PDRB based ConnstantPrices2000}

In addition through the PDRB at current prices, the success of the economic development of an area can also be seen through the development of the PDRB at constant prices. Along with the increase in PDRB at current prices, as described previously, based on constant price PDRB at current South Sulawesi economy also increased. This is seen in the value of PDRB at constant prices in 2006 which reached Rp. 38.87 trillion more and in 2010 had increased to Rp. 51.20 trillion more.

\section{Economic Growth of South Sulawesi}

Unlike the PDRB at current prices todescribe the structure of the economy of a region, then through constant price PDRB at current growth of the regional economy can be described from year to year. Through constant price PDRB at current mentioned above, it appears that during the period 2006-2010 South Sulawesi's economy grew an average of 7.13 percent per year, even when seen from the performance of the economy every year economic growth this area has fluctuated. Based on PDRB at constant prices in 2006, South Sulawesi's economy grew by 6.72 percent, from Rp. Over 36.42 trillion in 2005 to Rp. 38.87 trillion more in 2006 . Although the value of PDRB has increased to Rp. 41.33 trillion more in 2007, but growth is decreased to 6.34 percent, the decline was slight due to the impact of the economic crisis that occurred in that year. However, in 2008 the region was able to fix the economy so that growth of 7.78 per cent, but fell back in 2009 to reach 6.23 percent in 2010 and grew back up to 8.18 percent, from Rp. Over 47.33 trillion in 2009 to Rp. 51.20 trillion more in 2010.

\section{Human Development Index}

Human Development Index is an indicator for look at the performance of human development of a region. Melelui indicators of human development index, it is known the achievements of development policy by looking at life expectancy is increasing, the ability to read and write, the ability to follow every level of education and ability to meet its needs through purchasing power.

Particularly relevant when used as indicators of development outcomes because it is associated with the South Sulawesi Provincial Government's vision to make this area as a province of the ten best in the fulfillment of people's basic rights with HDI indicators, the HDI is a key indicator of success in achieving the vision in seeing the development of this area. 
The Impact of Buying Direct of Educational, Health and economic Sectors toward Human..

In the period 2006-2010, the HDI South Sulawesi which increased from 68.8 in 2006 to 71.6 in 2010. Despite the increase in the HDI figures appear but still lower than the national HDI. Based on these data sebumnya discussions that generally low compared to the HDI HDI South Sulawesi due to the low National Literacy Rate (AMH) and Average Old School (RLS) in this area. Both indicators HDI is below national values.

This study shows that the province Jump Shopping, Shopping Direct Education Sector, Health Sector and Economic Sector simultaneously have a significant effect on the Human Development Index of South Sulawesi with a significance level of 0.00 percent.

Based on the calculation of the regression in the table, it can be obtained by linear regression equation can be written as the following:

YHDI XI $=65.2+0.00070 .0015+0.0021+X 2+X 3+8(2)$

In the model studies have shown that the phenomenon of influence of variables Shopping Direct Education Sector, Health Sector Expenditures and Direct Shopping Direct Economic Sector to Development Index of South Sulawesi. It can be seen from the value Yhitung $(72,25)$ is greater than F table (9.28). Results shows the regression equation constants for 65.02. This means that if the variable Shopping Direct Education Sector, Health Sector Expenditures and Direct Expenditures Economic Sector no treatment / ignore the magnitude of the HDI South Sulawesi Province amounted to 65.02.

Education Sector Shopping Direct variable positively correlated with HDI. Independent variable coefficient Shopping Direct Education Sector (XI) of 0.0007 indicates that an increase of 1\% in Direct Spending in Education Sector will encourage an increase in the HDI of 0.0007 percent. Childhood education sector allocation effect can be understood as the ratio of direct spending on the education sector is small and direct spending cendurung decline in four years. It is the bottleneck to advancing education index that is significantly less influence on increased HDI.

The main problem in education is how to encourage students to continue their education to a higher level and low literacy rates. If the budget allocations for the education sector can directly resolve the issue then it can certainly encourage peningktan HDI South Sulawesi. Independent variable coefficient Shopping Direct Health Sector (X2) of 0.0015 indicates that an increase of 1\% in Shopping Direct Health Sector will encourage an increase in the HDI of 0.0015 percent. This means Shopping Direct Healthcare Sector is positively correlated with the Human Development Index of South Sulawesi. Independent variable coefficient Shopping Direct Economic Sector (X3) of 0.0021 indicates that if there is an increase in direct spending of $1 \%$ it will encourage increased HDI at 0.0021 percent. So, Shop Direct Healthcare Sector is positively correlated with the Human Development Index.

To determine the most influential variables can be seen predominantly $t$ value the most. Based on the analysis it can be concluded that the variable Shoppinglangsun Economic Sector (X3) the most influential because it has the largest $t$ value is equal to 4.546 and then Shopping Direct Healthcare Sector. While the effect was variable smallest Direct Expenditures by Education Sector t count equal to 0.071. Dominance of direct expenditure variable economic sectors Gumar Myrdal prove the theory that income will affect nutritional intake and the impact of public health back on productivity and income. Therefore, sufficient revenues to improve health and education that mark in improving the human development index HDI simultaneous crawl expected.

\section{Conclusion}

The results of the statistical analysis of $\mathrm{F}$ test showed that variables of buying direct in educational, health and economic sectors have simultaneously significant effect toward Human Development Index of South Sulawesi with a significance level of 0.00 percent. The low coefficient of all independent variables (education, health and economic) to HDI means the impetus to the growth of HDI South Sulawesi not significant causing the growth of HDI South Sulawesi just occupy ranked 19 of the 33 provinces in Indonesia. The results of the statistic analysis of $\mathrm{T}$ test showed that veriabel direct buying of economic sectors in partial has significant infleuence toward the Human Development Index with significance level of 0.0021 percent. The results of the statistica analysis of $\mathrm{T}$ test statistic of direct buying in educational and healt in partial have not significant influence toward Human Development Index of South Sulawesi.

\section{References}

[1]. Damanhuri,Didin. (2010).EkonomiPolitikdan Pembangunan, Bogor.HDI Press dan STEI Taskia

[2]. Musgrave, Richard A. \& Peggy B. Musgrave, 1989, Public Finance in Theory And Practice, Singapore, McGraw-Hill, $5^{\text {th }}$ edition

[3]. Suparmoko, M., 1996. Keuangan Negara: DalamTeoridanPraktek, CetakanKeenam, Yogyakarta: BPFE..

[4]. Todaro, Michael P., 1998. Pembangunan Ekonomi: Di DuniaKetiga(terjemahan), EdisiKeenam, Jakarta: PenerbitErlangga.

[5]. Sullivan ,A.2000.Urban Economics .Boston Irwin .McGraw Hill

[6]. UNDP.1995.Human Development Report.1995.UNDP New York.

[7]. BadanPusat Statistik. Sulawesi Selatan. HDI 2005-2010.Badan Pusat Statistik Sulsel Makassar

[8]. Badan Pusat Statistik,Produk Domestik Regional Bruto Provinsi Sulawesi Selatan 2005-2010. Badan Pusat Statistik Sulsel Makassar. 
The Impact of Buying Direct of Educational, Health and economic Sectors toward Human..

[9]. Pemendagri1 No.13 Tahun 2006

[10]. Soerkawi,1998.Prinsip-Prinsip dasarEkonomiPertanian :UI Press Jakarta

[11]. Sony Yuwono dkk.2008. Memahami APBD danPermasalahannya.Bayu Media Publishing.Malang

[12]. Undang-undang no.32 Tahun 2004 tentang Pemerintahandaerah

[13]. Undang-undang no.17 Tahun 2003 tentangKeuangan Negara

[14]. APBD Provinsi Sulawesi Selatan Tahun 2002-2010

[15]. Bappedda.Peraturan Daerah Provinsi Sulawesi Selatan tentang APBD. Ba 